J. AMER. SOC. HORT. SCI. 118(1):77-80. 1993.

\title{
Molecular Characteristics of Pectic Constituents in Relation to Firmness, Extractable Juice, and Woolliness in Nectarines
}

\author{
L.J. von Mollendorff ${ }^{1}$ \\ Stellenbosch Institute for Fruit Technology, Private Bag X5013, Stellenbosch 7599, South Africa \\ O.T. de Villiers ${ }^{2}$ \\ Department of Botany, University of Stellenbosch, 7600, South Africa \\ G. Jacobs ${ }^{2}$ \\ Department of Horticulture, University of Stellenbosch, 7600, South Africa \\ I. Westraad ${ }^{1}$ \\ Stellenbosch Institute for Fruit Technology, Private Bag X5013, Stellenbosch 7599, South Africa \\ Additional index words. Prunus persica, viscosity
}

\begin{abstract}
Flavortop' nectarines [Prunus persica (L.) Batsch] were either stored for 4 weeks at $\mathbf{- 0 . 5 C}$ or not subjected to cold storage before being ripened at $15 \mathrm{C}$. The differences in extractable juice, woolliness, composition, and gelling characteristics of extracted pectins between the two treatments were determined during ripening. As ripening progressed, the extractable juice in both treatments decreased to low values after which it increased with further ripening. Woolliness only occurred in fruit that was cold stored. Nectarines became woolly from the 2nd day and peaked on the 6th day of ripening in fruit cold stored for 4 weeks. As fruit firmness decreased, the soluble pectin concentration increased to the same extent in both treatments at the expense of insoluble pectin. In cold-stored fruit, the viscosity of pectin increased gradually until the 6th day of ripening, while in noncold-stored fruit maximum viscosity was higher and occurred between the 4th and 6th day of ripening. From the 6th day, the viscosity decreased in both treatments to levels lower than the initial viscosity. The extractable juice was lowest when the viscosity of soluble pectins and percentage of woolly fruit were highest. Molecular mass distribution of soluble pectins decreased considerably during ripening at $\mathbf{1 5 C}$.
\end{abstract}

Conversion of insoluble pectic substances to soluble forms is an important factor in the mechanism of fruit softening during ripening (Ben-Arie and Lavee, 1971; Chang and Smit, 1973; Kertesz, 1951; Pressey et al., 1971; Shewfelt et al., 1971). However, peaches stored at temperatures $<8 \mathrm{C}$ for long periods develop a woolly condition, and the characteristics of pectin conversion differs from that of normally ripened fruit (Lill et al., 1989).

Ben-Arie and Lavee (1971) showed that woolliness of 'Elberta' peaches is related to higher levels of protopectin and deesterified pectate during ripening after harvest. Changes in texture in peaches that develop woolliness are thought to be related to an increase in pectinmethylesterase (PME; EC 3.1.1.11) and a decrease in polygalacturonase (PG; EC 3.2.1.15) activity after a period of 2 weeks at cold-storage temperatures that induce woolliness (Ben-Arie and Lavee, 1971; Buescher and Furmanski, 1978).

Chang and Smit (1973) concluded that peach pectins are normally poor gel formers due to the presence of acetyl groups, high methoxyl levels, and relatively low molecular masses. In woolly fruit, the longer pectin chains and more deesterified pectate (Ben-Arie and Lavee, 1971) appear to favor gel formation (Lill et al., 1989).

Received for publication 18 Sept. 1992. Accepted for publication 28 June 1992. Based on part of a thesis accepted for a PhD at the Univ. of Stellenbosch, Stellenbosch. The cost of publishing this paper was defrayed in part by the payment of page charges. Under postal regulations, this paper therefore must be hereby marked advertisement solely to indicate this fact.

${ }^{1}$ Research Scientist.

${ }^{2}$ Professor.
Chang and Smit (1973) also showed that the viscosity of soluble pectin is higher in green than in ripe peaches and concluded that the molecular mass of pectins in green fruit is, therefore, much higher than in ripe fruit. Pressey and Avants (1973) found that the molecular mass of peach pectin ranges from $\approx 100$ $\mathrm{kDa}$ to several thousand and decrease progressively during ripening. Von Mollendorff and De Villiers (1988) found that the viscosity of soluble pectin in peaches cold stored after a delay period of $48 \mathrm{~h}$ at $23 \mathrm{C}$ reached a maximum during cold storage. However, viscosity in fruit cold stored immediately after harvest reached a maximum during ripening and was accomplished by a high percentage of woolly fruit. From this they concluded that woolliness develops in the presence of a high concentration of soluble pectin with a high molecular mass.

Von Mollendorff et al. (1989) found that when 'Independence' nectarines were cold stored for 4 weeks at $-0.5 \mathrm{C}$, they passed through the woolly stage during ripening at 10 and $20 \mathrm{C}$. They concluded that PG was not deactivated during the development of woolliness and that pectins with high molecular mass, participating in the formation of a gel structure, were hydrolyses to smaller units without gelling properties.

The purpose of this study was to determine whether there were differences in the composition and gelling characteristics of extracted pectins in 'Flavortop' nectarines stored for 4 weeks at $-0.5 \mathrm{C}$ before being ripened at $15 \mathrm{C}$ or being ripened immediately after harvest.

Abbreviations: AGA, anhydrogalacturonic; AIS, alcohol insoluble solids; GA, galacturonic acid; PG, polygalacturonase PME, pectinmethylesterase; PP, protopectin; SP, soluble pectin. 


\section{Materials and Methods}

\section{Experimental fruit}

Sixty cartons of 'Flavortop' nectarines were obtained from a commercial farm in the Elgin area in South Africa. Fruit 59 to $65 \mathrm{~mm}$ in diameter were selected for the experiment. At harvest, mean fruit firmness ranged from 88 to $98 \mathrm{~N}$ (representative sample of 30 fruit). Firmness was measured by an Effigi penetrometer (Effigi, Alfonsine, Italy) fitted with an 11-mm probe. Immediately after harvest, 30 cartons of the fruit were stored at $-0.5 \mathrm{C}$ with a relative humidity $(\mathrm{RH})$ of $85 \%$ to $90 \%$ for 4 weeks and then ripened at $15 \mathrm{C}$ in controlled-temperature rooms. The other 30 cartons were ripened at $15 \mathrm{C}$ immediately after harvest without any cold storage. Samples of 60 fruit from each treatment were taken and tested for firmness, extractable juice, and woolliness every second day during ripening for 13 days as described by Von Mollendorff et al. (1989). At each examination, half of each sample of 60 fruit was frozen immediately in liquid $\mathrm{N}$ and stored at $-30 \mathrm{C}$ for pectin analysis.

Woolliness was assessed by eye on each of the 60 fruit mentioned above. Fruit were cut in halves and squeezed. If the juice of the fruit appeared thick and did not flow freely from squeezed fruit or the tissue appeared dry, the fruit was considered to be woolly.

\section{Pectin analysis}

Alcohol insoluble solids (AIS) were extracted from fruit stored at -30C. Fruit was homogenized (25 g each from 10 nectarines) in a Waring Blender. AIS were extracted three times with $300 \mathrm{ml}$ of $70 \%$ ethanol, and a fourth time with $100 \mathrm{ml} 100 \%$ acetone at room temperature. Soluble pectin (SP) was extracted at room temperature from the AIS fraction as follows: 0.2-g AIS was vigorously stirred for $12 \mathrm{~h}$ with $20-\mathrm{ml}$ distilled water, then centrifuged at $27,000 \times \mathrm{g}$ for $20 \mathrm{~min}$. This procedure was repeated three to seven times until no galacturonic acid (GA) was detected in the supernatant (Blumenkranz and Asboe-Hansen, 1973). The supernatants were pooled. The pellets were subjected to calcium pectate $(\mathrm{CaP})$ extraction as follows: $25 \mathrm{ml}$ of a solution containing $0.1 \mathrm{M}$ Tris/ $\mathrm{HCl}$ buffer and $0.2 \%$ EDTA at $\mathrm{pH} 6.2$ were added to the pellet, shaken overnight, and centrifuged four times until no GA was detected in the supernatant. Protopectin (PP) was extracted from the final pellet with $25 \mathrm{ml}$ of a solution containing $1 \mathrm{ml}$ of pectin enzyme solution $(5 \%$ Spark L $+1 \%$ Ultrazyme) in $0.1 \mathrm{M}$ Tris/HCl buffer ( $\mathrm{pH} 5.6$ ). The solution was shaken for $16 \mathrm{~h}$ and centrifuged at 27,000x $\mathrm{g}$ for $20 \mathrm{~min}$. The supernatant was pooled with those of $\mathrm{CaP}$ to determine the total PP content. The amount of each pectin fraction was assessed calorimetrically (Blumenkranz and AsboeHansen, 1973) and calculated as the amount of GA per $100 \mathrm{~g}$ fresh fruit sample.

\section{Isolation of water-soluble pectin}

AIS $(0.1 \mathrm{~g})$ was added to $250 \mathrm{ml}$ of water and stirred for 12 $\mathrm{h}$ at room temperature. Samples were centrifuged $(8000 \times \mathrm{g}$ for $20 \mathrm{rein}$ ) and the supernatant concentrated to $50 \mathrm{ml}$ in an evaporator. Three volumes of ethanol and two volumes of actone were added to the solution. The precipitated pectin was washed with acetone and dried at $40 \mathrm{C}$.

\section{Viscosity of soluble pectins}

AIS (5 g) was stirred in $100 \mathrm{ml} 0.2$ sodium acetate buffer, $\mathrm{pH} 5.0$, for $12 \mathrm{~h}$. The suspension was then centrifuged at $27,000 \times$ $\mathrm{g}$ for $20 \mathrm{~min}$. The viscosity of the supernatant was determined with a Cannon (Model 100 A 289) viscosimeter (London) at $30 \mathrm{C}$. The viscosity of the soluble pectin $\left(\mathrm{n}_{\mathrm{sP}}\right)$ was expressed according to Doesburg (1965) and calculated as follows: $\mathrm{n}_{\mathrm{sP}}=$ $\mathrm{n}-\mathrm{n}_{\mathrm{O}} / \mathrm{n}_{\mathrm{O}}$, where $\mathrm{n}=$ viscosity of pectin solution and $\mathrm{n}_{\mathrm{O}}=$ viscosity of the solvent.

\section{Determination of molecular mass distribution of water- soluble pectin}

A $2.5 \times 80-\mathrm{cm}$ column of Bio-Gel A-50m, 100 to 200 mesh (Richmond, Calif.), was prepared by washing with $0.02 \mathrm{M}$ sodium acetate buffer ( $\mathrm{pH}$ 6.0).

Two milliliters of a $0.2 \%$ solution of each sample of SP was applied to the column and eluted with $0.02 \mathrm{M}$ acetate. Five milliliters fractions were collected and analyzed for anhydrogalacturonic acid (AGA) according the method of Blumenkranz and Asboe-Hansen (1973). For each fraction, the AGA content was added to the sum of the AGA contents of all preceding fractions. The percentage of AGA eluted up to each fraction was then calculated and plotted against the elution volume. Standard dextrans of known molecular mass were run on the same column comparison.

\section{Statistical analysis}

Experiments were laid out in a complete randomized design, analysis of variance was performed, and student's least significant difference (LSD) was calculated to compare treatment means (Snedecor and Cochran, 1980). The mean of two samples was used to determine the molecular mass distribution of soluble pectins. No statistical analysis was performed on the subjective evaluation of the percentage woolly fruit.

\section{Results and Discussion}

During the 4 weeks of cold storage, fruit firmness of 'Flavortop' nectarines decreased by $\approx 15.7 \mathrm{~N}$ to $82.3 \mathrm{~N}$ at the start of ripening. Noncold-stored fruit had a mean firmness of 98.0 $\mathrm{N}$ directly after harvest (Fig. 1; top). Fruit firmness decreased rapidly during ripening in both treatments and stabilized at $\approx 19.6$ $\mathrm{N}$ as fruit became fully ripe. The difference in fruit firmness between the two treatments decreased as ripening progressed; from the 6th day there was no significant difference between the treatments.

Except on the 2nd day of ripening, there was no significant difference in extractable juice between fruit cold stored and those not subjected to cold storage (Fig. 1; middle). The extractable juice decreased to a minimum of $11 \%$ and $17 \%$ for cold stored and noncold-stored fruit, respectively, on the 6th day of ripening. Thereafter, extractable juice increased as ripening progressed. These results agree with earlier findings (Von Mollendorff et al., 1989). Gelling of water by soluble pectins possibly explains the reduction in the extractable juice during ripening. High molecular mass peach pectins can form pectin gels (Ben-Arie and Sonego, 1980; Von Mollendorff et al., 1989).

Woolliness only occurred in cold-stored nectarines (Fig. 1; bottom) and increased progressively from $13 \%$ on the 2 nd day of ripening to $85 \%$ on the 6 th day of ripening. The maximum incidence of woolly fruit coincided with minimum values of extractable juice. With further ripening, the incidence of woolly fruit decreased as the extractable juice increased. On the 13th day of ripening, all fruit passed the woolliness stage and were similar in appearance and juiciness to those that were allowed 

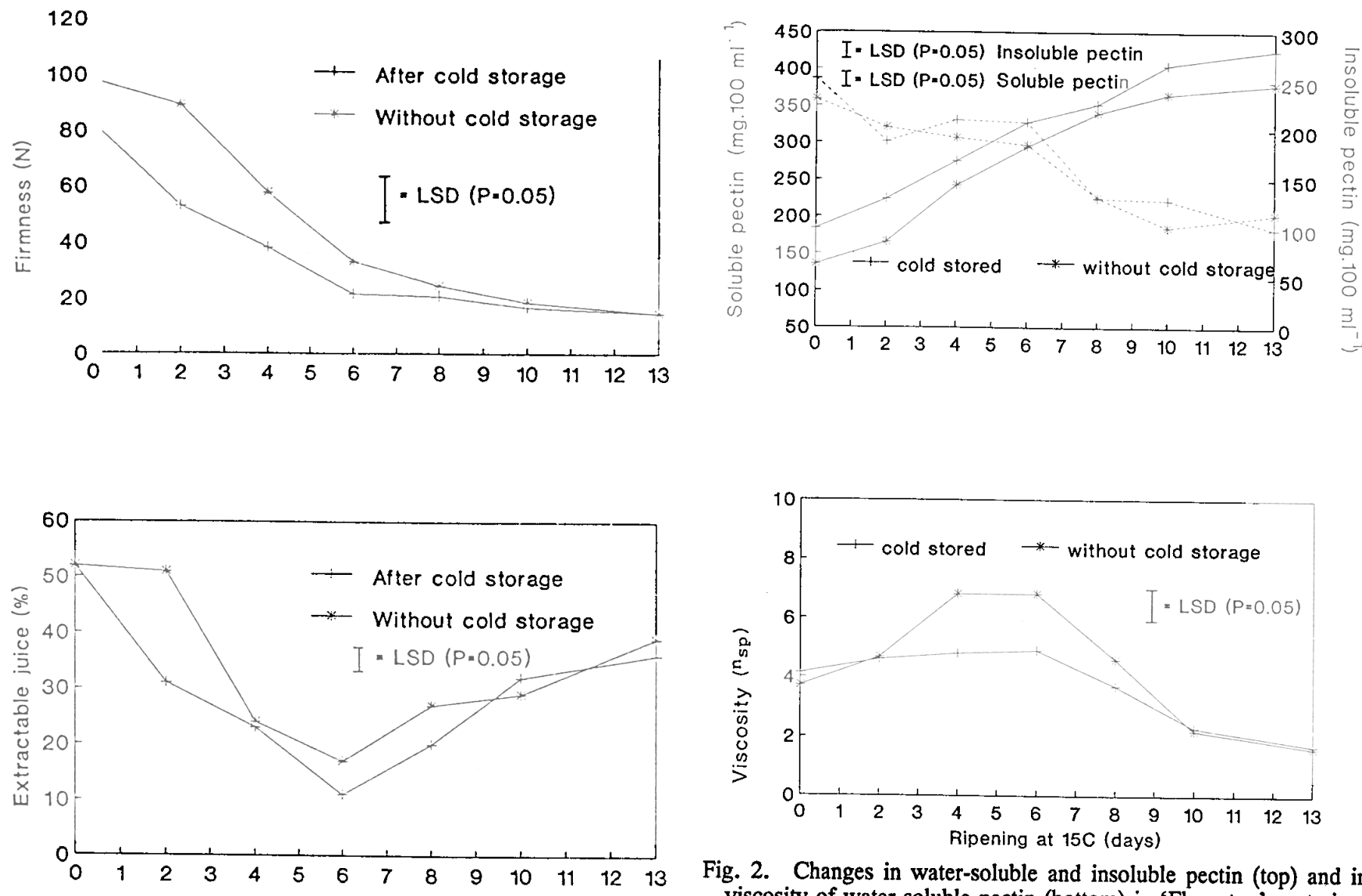

Fig. 2. Changes in water-soluble and insoluble pectin (top) and in viscosity of water-soluble pectin (bottom) in 'Flavortop' nectarines during ripening at $15 \mathrm{C}$ without cold storage $\left({ }^{*}\right)$ and after 4 weeks of cold storage at $-0.5 \mathrm{C}(+)$.

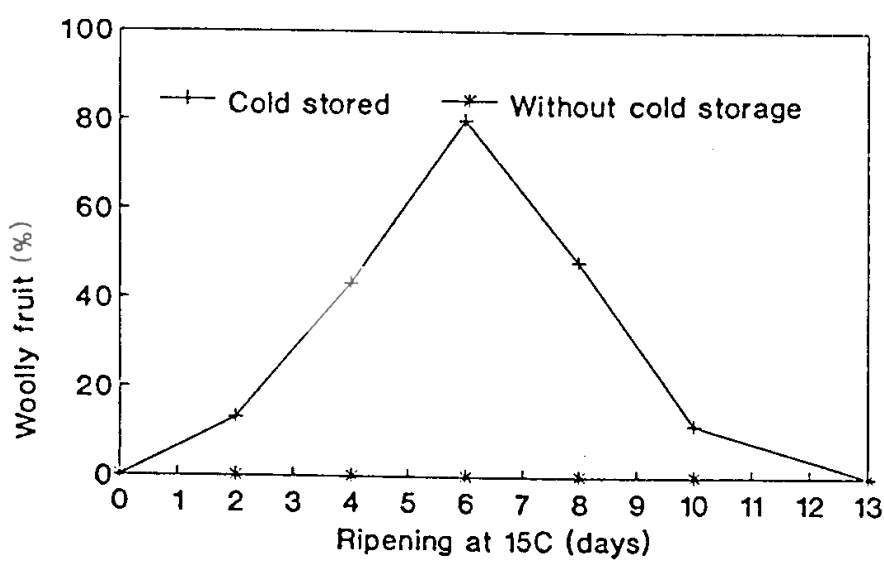

Fig. 1. Changes in firmness (top), extractable juice (middle), and woolliness (bottom) in 'Flavortop' nectarines during ripening at $15 \mathrm{C}$ without cold storage $\left(^{*}\right)$ and after 4 weeks of cold storage at $-0.5 \mathrm{C}$ $(+)$.

to ripen immediately after harvest and had not been subjected to cold storage.

As fruit firmness decreased, soluble pectin concentration in both treatments increased at the expense of insoluble pectin (Fig. 2; top). Noncold-stored fruit were firmer than cold-stored fruit at the beginning of ripening and had a lower concentration of soluble pectin. However, the concentration of SP in both treatments increased at about the same rate as ripening progressed (Fig. 3). Various researchers have indicated that the

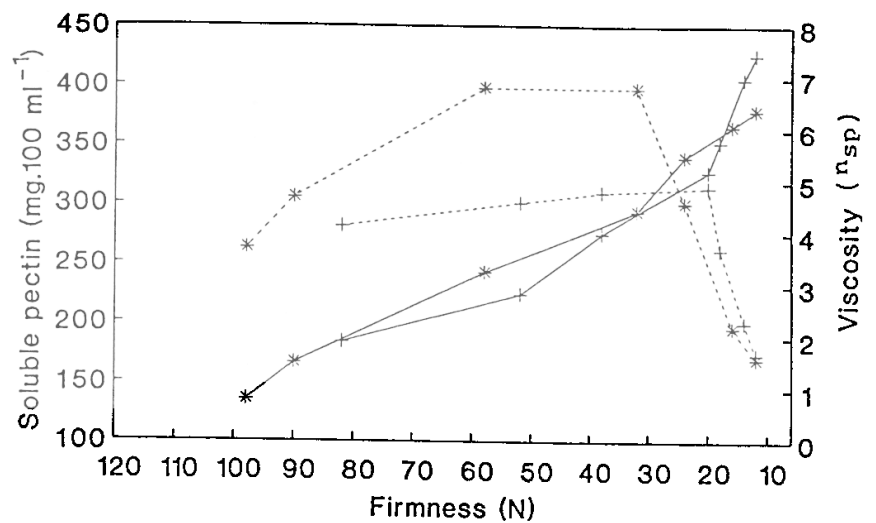

Fig. 3. Changes in water-soluble pectins (__ $)$ and in viscosity of water-soluble pectins (- - ) in relation to the decrease in fruit firmness in 'Flavortop' nectarines during ripening at $15 \mathrm{C}$ without cold storage $\left({ }^{*}\right)$ and after 4 weeks of cold storage at $-0.5 \mathrm{C}(+)$.

conversion of insoluble pectic substances to soluble forms is an important factor in the mechanism of fruit softening associated with ripening (Kertesz, 1951; Pressey et al., 1971; Shewfelt et al., 1971).

After 2 days of ripening, there was no significant difference in viscosity of SP between fruit cold stored and fruit not cold stored, but the viscosity of cold stored fruit increased to a maximum of 5.0 on the 6th day of ripening, while that of noncoldstored fruit increased to 6.8 between the 4th and 6th day of ripening (Fig. 2; bottom). This increase occurred irrespective 
of the difference in firmness at the beginning of the ripening period (Fig. 1; top). The higher viscosity of pectin in noncoldstored fruit between the fourth and sixth day of ripening was possibly due to a higher molecular mass distribution of soluble pectin as well as an increase in the concentration of soluble pectins (Chang and Smit, 1973; Doesburg, 1965; Pressey et al., 1971; Shewfelt et al., 1971). The increase in viscosity could also be the result of higher PME activity in noncold-stored fruit than in cold stored fruit since Doesburg (1965) showed that a decrease in the methoxyl level resulted in an increase in the gelling ability of pectins. This finding is in contrast with an earlier one by Ben-Arie and Lavee (1971) who found lower methoxyl levels and an increase in the gelling properties of SP of cold-stored fruit. From the 6th day, the viscosity of pectin in both treatments decreased gradually from $6.8 \mathrm{n}_{\mathrm{sP}}$ until the 13th day when it was $\approx 1.6 \mathrm{n}_{\mathrm{sP}}$ for both cold-stored and noncoldstored fruit.

The molecular mass of SP in nectarines changed considerably during ripening at $15 \mathrm{C}$, especially after the cold storage period (Fig. 4). About $75 \%$ of the water-soluble pectin isolated from 'Flavortop' nectarines at harvest and after 6 days of ripening, as well as after 4 weeks of cold-storage, was extracted in the first $240 \mathrm{ml}$. The elution volumes for dextran $\mathrm{M}_{\mathrm{r}}=150 \mathrm{kDa}$, dextran $M_{r}=270 \mathrm{kDa}$, and dextran $\mathrm{M}_{\mathrm{r}}=600 \mathrm{kDa}$ were 300 $\mathrm{ml}, 275 \mathrm{ml}$, and $240 \mathrm{ml}$, respectively. Plotting the elution volumes against the logarithms of molecular mass yielded a straight line. Compared with the standard dextrans, $\approx 75 \%$ of the pectin had a molecular mass $>600 \mathrm{kDa}$, while only $10 \%$ corresponded to a molecular mass of dextran of $<150 \mathrm{kDa}$.

The molecular mass distribution of SP did not change significantly during the first 7 days without cold storage, while in cold stored fruit it progressively decreased during the same period (Fig. 4). After 6 days of ripening, only 55\% of the SP was eluted in the first $240 \mathrm{ml}$, while by the 13th day, the molecular masses in both treatments were similar and were the lowest at any stage during ripening. For example, $25 \%$ to $30 \%$ of the pectin was eluated after $240 \mathrm{ml}$ of eluate, and $\approx 45 \%$ to $40 \%$ of the pectins had a molecular mass smaller than 150,000 . These findings agree with those of Pressey et al. (1971) and Chang and Smit (1973), who concluded that the molecular mass of SP in peaches decreased drastically with ripening.

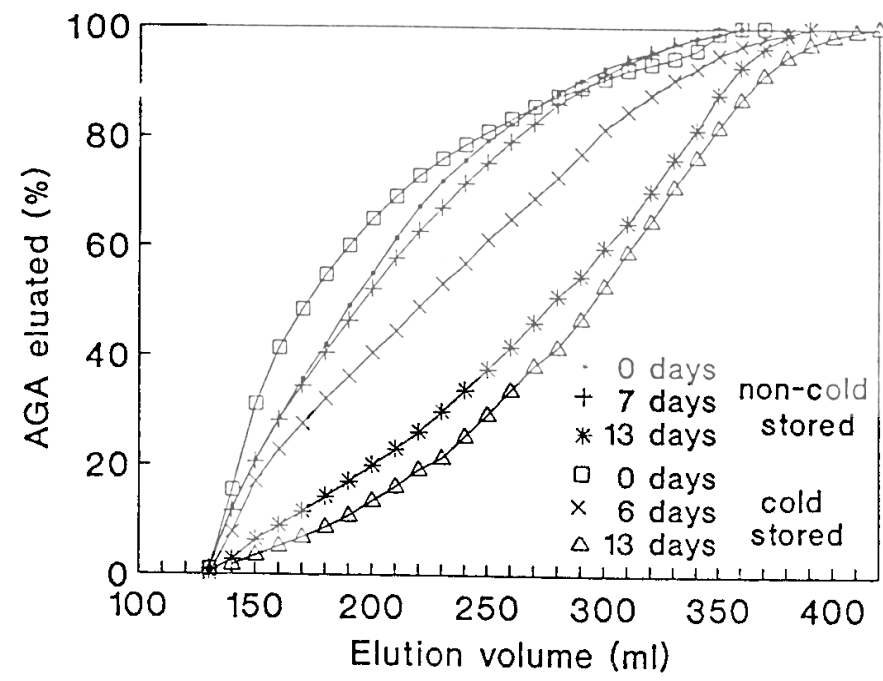

Fig. 4. Changes in elution patterns of water-soluble pectins extracted from 'Flavortop' nectarines during ripening at $15 \mathrm{C}$ without cold storage and after 4 weeks of cold storage at $-0.5 \mathrm{C}$.
Clearly, factors other than molecular mass and concentration of pectic substances must be involved in the development of woolliness because noncold-stored fruit had low levels of extractable juice $(\approx 18 \%)$ on the 6th day of ripening, and pectins of a higher molecular mass distribution on the same day, but no woolliness was present in the fruit.

Within certain limits, an increase in the methoxyl level, some degree of esterification and/or a decrease in the molecular mass and concentration of pectin will reduce the formation of pectin gels (Doesburg, 1965). In this study, cold-stored fruit on the 6 th day of ripening had a lower molecular-mass distribution, a higher concentration of SP, and the highest viscosity, possibly indicating that at this particular stage of ripening the right balance existed between molecular mass and pectin concentration for the formation of gels. Many authors agree that abnormal ripening of cold-stored fruit is caused primarily by membrane disfunction (Bramlage, 1982; Levitt, 1980; Morris, 1982; Wang, 1982). We therefore propose that during the development of woolliness, fluids and solutes leak through the membrane (as a result of long cold storage) and bind to high-molecular-mass pectins to form pectin gels in the intercellular spaces, giving rise to the typical dry texture observed in woolly fruit.

Chang and Smit (1973) mentioned that peach pectins are generally poor gel formers because of the presence of acetyl groups, high methoxyl levels, and relatively low molecular masses. Therefore, lower-molecular-mass pectins, such as those found in fully ripe fruit (e.g., after 13 days of ripening in this study), possibly will lose their gelling properties. This possibility is supported by the lower viscosity of SP, despite its higher concentration, on the 13th day of ripening. The end result was an increase in extractable juice and a decrease in woolliness.

\section{Literature Cited}

Ben-Arie, R. and S. Lavee. 1971. Pectic changes occurring in Elberta peaches suffering from woolly breakdown. Photochemistry 10:531-538.

Ben-Arie, R. and L. Sonego. 1980. Pectolytic enzyme activity involved in woolly breakdown of stored peaches. Photochemistry 19:2553-2555.

Blumenkranz, N. and G. Aaboe-Hansen. 1973. New method for quantitative determination of uronic acid. Anal. Biochem. 54:484-489.

Bramlage, W.J. 1982. Chilling injuries of crops of temperate origin. HortScience 17:165-168.

Buescher, R.W. and R.J. Furmanski. 1978. Role of pectinesterase and polygalacturonase in the formation of woolliness in peaches. J. Food Sci. 43:264-266.

Chang, Y.S. and C.J.B. Smit. 1973. Characteristics of pectins isolated from soft and firm fleshed peach varieties. J. Food Sci. 38:646-648.

Doesburg, J.J. 1965. Pectic substances in fresh and preserved fruits and vegetables. H. Veenman and N.V. Zonen, Wageningen.

Furmanski, R.J. and R.W. Buescher. 1979. Influence of chilling on electrolyte leak. age and internal conductivity of peach fruit. HortScience 14:167-168.

Kertesz, Z.L. 1951. The pectic substances. Interscience Publ., New York.

Levitt, J. 1980. Responses of plants to environmental stresses. 2nd (cd.). vol. 1. Chilling, freezing and high temperature stresses. Academic Press, New York.

Lill, R.E., E.M. O'Donoghue, and G.A. King. 1989. Postharvest physiology of peaches and nectarines. Hort. Rev. 11:413-452.

Morris, L.L. 1982. Chilling injury of horticultural crops: An overview. HortScience 17:161-162.

Pressey, R. and J.K. Avants. 1973. Separation and characterization of endopolygalacturonase and exopolygalacturonase from peaches. Plant Physiol. 52252-256,

Pressey, R., D.M. Hinton, and J.K. Avants. 1971. Development of polygalacturonase activity and solubilization of pectin in peaches during ripening. J. Food Sci. 36:1070-1073

Shewfelt, A.L., V.A. Paynter, and J.J. Jen. 1971. Textural changes and molecular characteristics of pectic constituents in ripening peaches. J. Food Sci. 36:573-575.

Snedecor, G.W. and W.G. Cochran. 1980. Statistical methods. 7th (ed.). Iowa State Univ. Press, Ames.

Von Mollendorff, L.J. and O.T. De Villiers. 1988. Role of pectolytic enzymes in the development of woolliness in peaches. J. Hort. Sci. 63:53-58.

Von Mollendorff, L.J., O.T. De Villiers, and G. Jacobs. 1989. Effect of time of examination and ripening temperature on the degree of woolliness in nectarine. J. Hort. Sci. 64:443-447.

Wang, C.Y. 1982. Physiological and biochemical responses of plants to chilling stress. HortScience 17:173-186. 